IZA DP No. 4850

Recent Advances in the Economics of Individual Subjective Well-Being

Alois Stutzer

Bruno S. Frey

March 2010 


\title{
Recent Advances in the Economics of Individual Subjective Well-Being
}

\author{
Alois Stutzer \\ University of Basel, \\ CREMA and IZA \\ Bruno S. Frey \\ University of Zurich \\ and CREMA
}

\author{
Discussion Paper No. 4850 \\ March 2010 \\ IZA \\ P.O. Box 7240 \\ 53072 Bonn \\ Germany \\ Phone: +49-228-3894-0 \\ Fax: +49-228-3894-180 \\ E-mail: iza@iza.org
}

Any opinions expressed here are those of the author(s) and not those of IZA. Research published in this series may include views on policy, but the institute itself takes no institutional policy positions.

The Institute for the Study of Labor (IZA) in Bonn is a local and virtual international research center and a place of communication between science, politics and business. IZA is an independent nonprofit organization supported by Deutsche Post Foundation. The center is associated with the University of Bonn and offers a stimulating research environment through its international network, workshops and conferences, data service, project support, research visits and doctoral program. IZA engages in (i) original and internationally competitive research in all fields of labor economics, (ii) development of policy concepts, and (iii) dissemination of research results and concepts to the interested public.

IZA Discussion Papers often represent preliminary work and are circulated to encourage discussion. Citation of such a paper should account for its provisional character. A revised version may be available directly from the author. 
IZA Discussion Paper No. 4850

March 2010

\section{ABSTRACT}

\section{Recent Advances in the Economics of Individual Subjective Well-Being}

Over the last decades, empirical research on subjective well-being in the social sciences has provided a major new stimulus to the discourse on individual happiness. Recently this research has also been linked to economics where reported subjective wellbeing is often taken as a proxy measure for individual welfare. In our review, we intend to provide an evaluation of where the economic research on happiness stands and of three directions it might develop. First, it offers new ways for testing the basic assumptions of the economic approach and for going about a new understanding of utility. Second, it provides a new possibility for the complementary testing of theories across fields in economics. Third, we inquire how the insights gained from the study of individual happiness in economics affect public policy.

JEL Classification: A10, D60, H41, I31

Keywords: economics, happiness, life satisfaction, survey data, income, public goods, unemployment

Corresponding author:

Alois Stutzer

Department of Business and Economics

University of Basel

Peter Merian-Weg 6

$\mathrm{CH}-4002$ Basel

Switzerland

E-mail: alois.stutzer@unibas.ch 


\section{Introduction}

Questions about the good life and individual happiness have a long tradition in philosophy. For centuries, people developed ideas about the nature of human flourishing and well-being, its sources and its relevance for individual behavior. ${ }^{1}$ Over the last decades, empirical research on subjective well-being in the social sciences has provided a major new stimulus to the discourse on individual happiness. Initially, the empirical study of happiness has been mainly the province of psychology. ${ }^{2}$ However, there have also been important contributions by sociologists and political scientists. ${ }^{3}$ Only recently has this research been linked to economics. The early contribution of Richard Easterlin (1974) was noted by many economics scholars, but at the time it found few followers. The same may be said of Tibor Scitovsky's book The Joyless Economy (1976). ${ }^{4}$ The situation has changed substantially by now.

In this paper, we present recent contributions of economics to the study of individual happiness. They are based on a subjective view of utility recognizing that everyone has his or her own ideas about happiness and the good life, and that observed behavior is an incomplete indicator of individual well-being. If one adopts this view, an individual's welfare can nevertheless be captured and analyzed: a person can be asked how satisfied he is with his or her life. It is a sensible tradition in economics to rely on the judgment of the persons directly involved. People are considered to be good judges of the overall quality of their lives, and it is a straightforward strategy to ask them about their well-being.

Much of previous happiness research in economics takes reported subjective well-being as a proxy measure for individual welfare whereby "subjective well-being" is the scientific term used in psychology for an individual's evaluation of the extent to which he or she experiences

\footnotetext{
${ }^{1}$ For useful histories of how philosophers have dealt with the topic of happiness, see, e.g., McMahon (2006) and Bruni (2006). The contributions of Aristotle, Bentham, Mill, and Kant are also discussed in Bruni and Porta (2007), Sugden (2005) and Nussbaum and Sen (1993).

${ }^{2}$ See, in particular, the contributions by Argyle (1987), Csikszentmihalyi (1990), Michalos (1991), Diener (1984), Diener and Biswas-Diener (2008), Myers (1993) and Ryan and Deci (2001).

${ }^{3}$ For the former group, see, e.g., Veenhoven $(1993,1999)$ and for the latter group Inglehart (1990) and Lane (2000). Notable forerunners exploring the epidemiology of happiness are Cantril (1965), Bradburn (1969), Andrews and Withey (1976) and Campbell et al. (1976).

${ }^{4}$ Even earlier, Bernard van Praag and his group in Leyden (1968) developed the concept of individual welfare functions. They can be considered a related concept based on reported subjective evaluations.
} 
positive and negative affect, happiness, or satisfaction with life. This indicator offers a complementary approach to traditional welfare measure focusing on individual income or Gross National Product per capita. Measures of subjective well-being allow for the study of the relationship between individual well-being and economic conditions such as income, unemployment, inflation and inequality and the analysis of the determinants of individual well-being in general. It is understood that economic activity is certainly not an end in itself, but only has value in so far as it contributes to human happiness. ${ }^{5}$

This research has already produced many interesting findings. There are several surveys of the state of economic research on subjective well-being available in the form of journal articles (e.g. Di Tella and MacCulloch 2006, Dolan et al. 2008, Frey and Stutzer 2002b, 2005) and books (e.g., van Praag and Ferrer-i-Carbonell 2004, Layard 2005, Bruni and Porta 2005, 2007, Frey and Stutzer 2002a, Frey 2008). In this review we intend to provide an evaluation of where the economic research on happiness stands and in which interesting directions it might develop. Accordingly, we discuss some research on the determinants of subjective well-being but mainly offer conceptual thoughts. We emphasize the potential of the approach to provide new insights in three directions.

First, it offers new ways for testing the basic assumptions of the economic approach and for arriving at a new understanding of utility in economics. Based on data on reported subjective well-being, it is possible to address fundamental questions like, for example, 'Do people evaluate outcomes in absolute or in relative terms?', 'How does the process of decisionmaking affect individual well-being?', 'Can people successfully predict their future utility and preferences?' or 'Does consumption choice reflect time consistent preferences?' These questions are closely connected to the research program of scientists in the cross-disciplinary field of economics and psychology. ${ }^{6}$

Second, research on subjective well-being provides a new possibility for the complementary testing of theories across fields in economics. For example, it allows discriminating between models that predict the same patterns of behavior but predict differences in experienced

\footnotetext{
${ }^{5}$ There is, of course, the fundamental issue of whether happiness is the ultimate goal to be pursued. Other valid goals, for instance, may be loyalty, responsibility, self-esteem, freedom or personal development.

${ }^{6}$ Introductions to the literature in so-called "behavioral economics" or "economics and psychology" are provided, e.g., by Camerer et al. (2003), Frey and Stutzer (2001, 2007), Rabin (1998).
} 
utility. This complementary evidence helps to additionally analyze certain models and their policy recommendations. Moreover, based on a proxy measure for individual welfare, "net" effects of different institutions on people's well-being can be assessed, e.g. of labor market institutions or of institutions of direct democratic political decision-making.

Third, we inquire how the insights gained from the study of individual happiness in economics affect public policy. Following the constitutional point of view there are two levels at which policy decisions are taken: In the current politico-economic process within given rules, and at the constitutional level, where the rules of the game as such are determined. We argue, and illustrate this by resorting to concrete results of happiness research, that there are impulses on both levels. Thereby, our discussion should make clear that the policy approach matters for the choice of research questions and thus for the kind of knowledge happiness research aims to provide, as well as for the people seen as addressees. We emphasize that there is no shortcut to an optimal happiness policy maximizing some aggregate happiness indicator as a social welfare function.

The paper is organized as follows. Section 2 provides a primer on the new approach of measuring individual welfare. The following two Sections 3 and 4 discuss the relationship between two important economic variables and subjective well-being, i.e. income and unemployment. For income, we emphasize the role of income aspirations in the notion of relative utility. For unemployment, we contrast the views that it occurs as a voluntary or an involuntary act. Section 5 addresses challenges to the rational consumer hypothesis due to limited will power and utility misprediction that can be studied based on reported welfare judgments. In section 6, we discuss how happiness research matters as regards the currentpolitico-economic process as well as the constitutional level. Concluding remarks are offered in Section 7.

\section{Measuring Individual Welfare}

\subsection{Reported Subjective Well-Being}

In received economics, utility is what is maximized when people choose between alternatives, i.e. a representation of preferences that are simply choice-connected rankings of outcomes. According to the axiomatic approach, individuals' choices provide all the information required to infer the utility of outcomes. Welfare judgments can be made by resorting to the Pareto criterion and therefore no comparison of welfare levels among individuals is required. 
Subjectivist experience captured by surveys is rejected as being not objectively observable and unscientific.

This view is still predominant in economics. However, numerous scholars have challenged standard economic theory from different angles. There are countless examples of nonobjectivist theoretical analyses in economics. They incorporate emotions, self-signaling (selfesteem), goal completion, mastery, meaning and status. Moreover, the outcome orientation in standard economics is supplemented with individuals' concerns about the processes leading to outcomes. ${ }^{7}$ In the vast literature on anomalies in decision-making, it is questioned whether utility can generally be derived from observed choices. The same reservation applies to intertemporal choices when individuals suffer from problems of self-control. The exclusive reliance on an objectivist approach by standard economic theory is thus open to doubt, both theoretically and empirically. In any case, it restricts the possibility of understanding and influencing human well-being.

In recent economic research, new ways are pursued to approach individual welfare. Utility is again related to the original, Benthamite meaning of utility as the hedonic quality of experience, broadly construed to include satisfaction as well as pleasure. In many situations the choice-based and the experience- or survey-based concept of utility coincide but there is also evidence indicating that they may systematically diverge in some situations (see Section 5). Empirically, utility based on judgments of satisfaction and pleasure can be captured by measures of subjective well-being. ${ }^{8}$

Subjective well-being is the umbrella term for different measures that can be distinguished along two dimensions. Regarding the first dimension, a common distinction is made between cognition, i.e. the evaluative or judgmental component of well-being (usually assessed with life satisfaction), and affect, i.e. the pleasure-pain component of well-being (Diener 1984). With regard to affect, two independent components of positive and negative affect are differentiated. The second dimension distinguishes between measures that capture a person's level of subjective well-being and the duration in one rather than another mental state. Because life satisfaction is a relatively stable construct, duration measures usually refer to

\footnotetext{
${ }^{7}$ An introduction to the concept of procedural utility is provided in Frey et al. (2004).

${ }^{8}$ The empirical study of subjective well-being used to be the province of hedonic psychology (for reviews, see Diener et al. 1999; Kahneman et al. 1999).
} 
affect. A primary example of a duration measure is the U-index, which measures the proportion of time an individual spends in an unpleasant state (Kahneman and Kruger 2006).

The measures are elicited with (i) global self-reports in surveys, (ii) the Experience Sampling Method, which collects information on individuals' actual experiences in real time in their natural environments, and (iii) the Day Reconstruction Method, which asks people to reflect on how satisfied they felt at various times during the day (on the latter two techniques, see Stone et al. 1999; Kahneman et al. 2004). Further, neurophysiological correlates of subjective well-being have been found with electro-encephalography and neuroimaging techniques (Urry et al. 2004).

The various measures capture different aspects of individual well-being and thus different concepts of individual welfare. For a measure of reported subjective well-being to serve as a proxy for individual welfare, two important assumptions are necessary: First, the standards underlying people's judgments are those the individual would like to pursue in realizing his or her ideal of the good life. Second, people are assumed to pursue individual welfare based on some stable evaluation standards. Accordingly, the extent to which individual welfare is identified depends on whether the evaluation metric fits people's judgments about their lives.

The normative basis of this approach goes beyond assuming the pursuit of happiness, and also involves choosing the concrete evaluation metric to elicit people's judgments. Thus ambiguities remain when selecting the empirical concept in order to measure individual welfare. ${ }^{9}$ Some people might favor a distant look reflecting on one's life after the fact, while others favor the reasoned ex ante evaluations as their standards. Still others might give priority to how they felt when experiencing the course of life.

Imagine those people who see high individual welfare as something like the "positive, persistent attitude towards both particular experiences and life experience more generally that a person feels upon repeated reflection" (Kelman 2005, pp. 408-409). For them, general evaluations of their satisfaction with life as a whole might be an appropriate metric to capture judgments about individual welfare. For those people who equate individual welfare with moment-to-moment affect, individual welfare might be best measured by such approaches as Experience Sampling or the Day Reconstruction Method. When looking for an empirical tool

\footnotetext{
${ }^{9}$ An excellent account of the ambiguities of welfare in the context of economics and hedonic psychology is provided in Kelman (2005).
} 
to collect information about people's judgments, it is thus important to reveal the concrete metric.

Most of the empirical work undertaken so far on subjective well-being research in economics has been based on representative, large-scale sampling of individual global evaluations of life satisfaction. These measures are an attractive proxy measure for individual welfare as they offer a blend of cognitive judgment and affective state. ${ }^{10}$

\subsection{Do Measures of Subjective Well-Being Have Informative Value?}

The different measurement techniques and their corresponding measures all have their strengths and weaknesses. Which measure and measurement technique is to be preferred depends on its intended use. In the following, we list four criteria that are relevant for many applications in economics. We ask whether the measures are (i) valid proxies of individual welfare, (ii) broad and inclusive, (iii) interpersonally comparable, and (iv) have small measurement errors, and no systematic ones.

Validity. While we claimed the validity of subjective well-being measures at the outset of this review, we present here some specific evidence for reported satisfaction with life. Respondents who are satisfied with their lives are also rated as satisfied by family members, friends and experts (Sandvik et al. 1993). Life satisfaction scores correlate with other variables that can be plausibly claimed to be associated with true individual well-being (see Frey and Stutzer 2002b for references). In two 20-year follow-up studies, low levels of reported life satisfaction predicted mortality (i.e., all-cause, disease and injury mortality), especially for male respondents (Koivumaa-Honkanen et al. 2000) and suicide (KoivumaaHonkanen et al. 2001). In fact, the individual level correlates of suicide are remarkably similar to those of reported (un-)happiness (Daly and Wilson 2009).

Inclusiveness. Essentially, this criterion approaches the validity issue from a second angle. Subjective well-being is an appropriate empirical approximation of individual welfare if it is broad and all inclusive. We think that the current evidence supports this position. However, critics claim that subjective well-being is extremely narrow and constitutes only one of many components of individual welfare (Adler and Posner 2006, p. 77), one sub-utility function among others (Kimball and Willis 2006). This debate parallels the normative question of the

\footnotetext{
${ }^{10}$ Moreover, this kind of "affect-contaminated" cognition corresponds to what has been considered the best theory on the nature of welfare in philosophy (Sumner 1996, pp. 140-156).
} 
nature of welfare with the "objectivist" ascribing intrinsic importance to various goods and "subjectivists" conceding other goods only instrumental importance insofar as they contribute to well-being. The positive question asks whether other "higher order" goods are sub-utility functions of equal standing with subjective well-being or whether these goods are arguments in the subjective well-being function with no independent effect on individual utility.

Interpersonal comparability. An extreme view holds that it is in principle not possible to observe the level of an individual's utility and, therefore, compare utility levels of different persons (Robbins 1938). Individuals with identical preferences (as revealed through behavior) and with identical expressive reactions to any situation may nevertheless attach different utilities to identical situations. The practical question thus is whether identical (verbal and physiological) expressions reflect similar mental states and what the consequences for empirical research are if they do not.

Kahneman (2000) suggests that there is evidence of considerable interpersonal convergence in ranking of pleasure and pain. In painful medical procedures, for example, the relationship between expressed pain and physiological reactions is similar across persons. Similarly, the correlations between self- and other-reports discussed above show that self-reports are not just artifacts of individual specific response behavior but are related to shared standards of evaluation. More importantly, for most empirical research, comparisons at the individual level are not necessary. Instead, empirical analysis is focusing on groups and compares the subjective well-being of individuals under different circumstances, e.g. the subjective wellbeing of groups of individuals exposed to different levels of a public good. By focusing on groups, personal peculiarities of individuals counterbalance one another.

Measurement errors. The major concern in the discussion on the degree of inclusiveness is that measures of subjective well-being may exclude important aspects of utility. The converse concern is that measures of subjective well-being include a lot of noise and are contaminated by confounding factors. Most research on this problem has focused on global self-reports.

Normally, global judgments are only construed when asked. Answering the question involves cognitive (memory and aggregation) and communicative processes. At the level of cognitive processes, concerns may arise that respondents may make little mental effort and instead rely on easily accessible information. Experimental research shows that self-reports can be influenced by the immediate context as well as by artificially induced intra- and interpersonal comparisons and temporal mood states. At the level of the communicative process, issues of 
norms, self-representation and social desirability become important (Larsen and Frederickson 1999; Schwarz and Strack 1999).

In order to assess the importance of these findings, it is useful to integrate them into a measurement error framework. This allows distinguishing two types of errors: White noise errors that are unrelated to explanatory variables, and systematic errors that are correlated with the explanatory variables. Mood variability and most context effects fall in the first category. Conceptually, errors of this sort pose no problem. They entail no systematic bias as the idiosyncratic effects cancel each other out. However, the random variation reduces the statistical fit. Therefore, the ratio of error variance to true variance has to be sufficiently low to make statistical work productive.

Measurement errors that fall into the second category pose a more serious problem. Two findings of the experimental research are of particular interest. First, questions not related to well-being in the questionnaire, and the order of the questions can influence the reported subjective well-being. For example, if the questionnaire includes questions referring to the living conditions to be evaluated, these questions may systematically bias the results, especially if the questions precede the subjective well-being question. Second, answers deemed to be socially desirable or serving self-representation purposes can also systematically influence the results. Thus, problems of the second category have important implications for the questionnaire design and survey mode as well as for the choice of existing data.

There is still much room for improvements in the quality and the understanding of measures on subjective well-being. One question is whether people's instantaneous level of happiness can be captured by self-reported measures of well-being or whether there is a difference between people's hedonic experiences and their explicit reflective appraisals of experiences in reported subjective well-being (e.g. Schooler et al. 2003). Sometimes people are fully engaged in challenging activities and experience great pleasure (or "flow"). Because of the very nature of this situation, people will not assess and report their well-being when in such a state and thus set boundaries for the survey measurement of instant utility.

The shortcomings of subjective well-being measures today should be taken seriously and research on their improvement is worthwhile. However, when evaluating them, they should be compared with alternative limited concepts of measuring people's level of welfare (see, 
e.g., the Stiglitz Report by the Commission on the Measurement of Economic Performance and Social Progress 2009).

\subsection{The Correlates of Subjective Well-Being}

Provided that reported subjective well-being is a valid and empirically adequate measure for human well-being, it can be modeled in a microeconometric function $\mathrm{W}_{\mathrm{it}}=\alpha+\beta \mathrm{X}_{\mathrm{it}}+\varepsilon_{\mathrm{it}}$. Thereby, true well-being serves as the latent variable. $\mathrm{X}=\mathrm{x}_{1}, \mathrm{x}_{2}, \ldots, \mathrm{x}_{\mathrm{n}}$ are known variables, like sociodemographic and socioeconomic characteristics, or environmental, social, institutional and economic conditions for individual $\mathrm{i}$ at time $\mathrm{t}$. The model allows for the analysis of each factor that is correlated with reported subjective well-being separately. This approach has been successfully applied in numerous studies on the correlates of subjective well-being. Technically, multiple regression analyses are conducted. As the dependent variable is measured on a ranking scale, normally ordered logit or probit estimation techniques are applied.

The estimates provide a substantial number of new and insightful empirical findings (see the references in Section 1). For reasons of space, we only discuss results on the relationship between happiness and income as well as unemployment in the following two Sections.

\section{Income and Happiness: The Role of Income Aspirations}

Persons with higher income have more opportunities to attain whatever they desire: in particular, they can buy more material goods and services. It is therefore often taken as selfevident that higher income and consumption levels provide higher well-being. This conclusion also follows from the concept of utility in economics, which is based on a very simple psychological notion. Economics assumes that people always know what is best for them and that they make decisions accordingly. Moreover, it is assumed that people's utility depends on what they have in absolute terms. Research on subjective well-being allows us to test this notion empirically.

\subsection{Are People with High Income Happier? Paradoxical Empirical Findings}

The relationship between income and happiness at a particular point in time and place (country) has been the subject of a large empirical literature. As a robust and general result, it has been found that richer people, on average, report higher subjective well-being (see Clark et al. 2008 for a review). The relationship between income and subjective well-being, both in 
simple regressions and when a large number of other factors are controlled for in multiple regressions, proves to be statistically (usually highly) significant. With regard to this specific evidence, the standard economic view is confirmed in happiness research.

However, there is a second way to study the relationship between income and happiness. This refers to the question whether an increase in income over time raises reported subjective wellbeing. A striking and curious relationship is observed. There is evidence that people in industrialized countries are not becoming happier over time, despite economic growth. This has first been observed and documented by Easterlin (1974). ${ }^{11}$ As the two findings on the relationship between income and happiness cannot easily be aligned, they are often referred to as the Easterlin Paradox.

The Easterlin Paradox provoked reactions in two directions. One reaction was to challenge the empirical findings. Stevenson and Wolfers (2008), e.g., dismiss the long-term evidence for Japan as a result of changes in survey questions. Others document that there are Western countries like Denmark, Germany and Italy that experienced substantial real per capita income growth as well as a (small) increase in reported satisfaction with life in the 1970s and 80s (Diener and Oishi 2000). Moreover, the relationships presented between income and happiness over time are often not analyzed ceteris paribus. However, for the United States, a negative time trend is also found when individual characteristics are controlled for (Blanchflower and Oswald 2004). At the current state of empirical data, it is difficult to reject any hypothesis on statistical grounds with respect to whether no relationship or a positive relationship between income and subjective well-being over time is proposed.

Another position that can be taken is to accept that there is no clear cut trend, positive or negative, in self-reported subjective well-being over periods of twenty to thirty years in rich countries. Instead, the results indicate that there is more to subjective well-being than just the absolute level of income.

\subsection{The Missing Variable: Income Aspirations}

In order to shed light on the paradoxical findings, happiness research in economics has explored different aspects of a psychologically sounder concept of utility. Two processes are emphasized. First, one of the most important processes people go through is that of adjusting

\footnotetext{
${ }^{11}$ See also, e.g., Blanchflower and Oswald (2004), Easterlin (1995, 2001) and Easterlin and Angelescu (2009).
} 
to past experiences. Human beings are unable and unwilling to make absolute judgments. Rather, they are constantly drawing comparisons from the past or from their expectations of the future. Thus, we notice and react to deviations from reference levels.

Additional material goods and services initially provide extra pleasure, but it is usually only transitory. Higher happiness with material things wears off. Satisfaction depends on change and disappears with continued consumption. This process, or mechanism, that reduces the hedonic effects of a constant or repeated stimulus, is called adaptation. And it is this process of hedonic adaptation that makes people strive for ever higher aspirations (see Rayo and Becker 2007 for an evolutionary rationale of this process).

Second, there are social comparisons with relevant others. It is not the absolute level of income that matters most, but rather one's position relative to other individuals. Higher income people also have a higher relative income compared to others, and therefore a higher status in society. Socially comparative or even competitive processes in consumption complement processes of hedonic adaptation.

Many economists in the past have noted that individuals compare themselves to significant others with respect to income or consumption. Thorstein Veblen (1899) coined the notion of "conspicuous consumption", serving to impress other persons. The "relative income hypothesis" has been formulated and econometrically tested by James Duesenberry (1949), who posits an asymmetric structure of externalities. People look upwards when making comparisons. Wealthier people impose a negative external effect on poorer people, but not vice versa. As a result, savings rates depend on the percentile position in the income distribution, and not solely on the income level, as in a traditional savings function.

It is suggested that the two processes make people strive for ever higher aspirations. Together, they can also explain why persons with high income at a given point in time report higher subjective well-being than those with low income (social comparison effect) while there is no clear statistical relationship between income per capita and average life satisfaction in industrialized countries over time (adaptation effect).

There is now also direct empirical evidence for the important role of income aspirations in individual welfare from two empirical studies for Germany and Switzerland (Stutzer 2004, Stutzer and Frey 2004). This is made possible by using two data sets that both include 
individual data on reported satisfaction with life, as well as income evaluation measures as proxies for people's aspiration levels. ${ }^{12}$

It is found that higher income aspirations reduce people's satisfaction with life. In Switzerland and the New German Laender, the negative effect of an increase in the aspiration level on well-being is of a similar absolute magnitude as the positive effect on well-being of an equal increase in income. This suggests that subjective well-being depends largely on the gap between income aspirations and actual income and not on the income level as such. Thus, the higher the ratio between aspired income and actual income, the less satisfied people are with their lives, ceteris paribus. This supports the notion of a relative utility concept.

Both studies also explore the determinants of income aspirations. The econometric results show that, consistent with processes of adaptation, income aspirations increase with personal income. However, the effects of higher income on individual well-being at a fixed point in time are not completely counterbalanced by higher aspirations. In fact, for rich people, the relative gap between income aspirations and actual income is smaller. This can explain the positive correlation between income and reported subjective well-being. For the analysis of relative income concerns in the Swiss data set, individuals' aspirations are merged with data on aggregate income in the community where people live. The results indicate that a higher average income in the community increases people's levels of aspiration. This effect cannot be explained by a higher cost of living alone. It is shown that the aspiration levels of community members who interact within their community react much more to changes in average income than those of members who do not interact.

What are the consequences of research on relative income? The empirical basis is still relatively small to be able to draw firm implications for economic theory and economic policy. Caution is required because the implications might be far-reaching. However, it might be worthwhile to consider household theory, in which people's desires increase according to what they get. In this framework, the marginal utility of income would no longer be constant, as the utility function changes with the income level. It would be interesting to study in

\footnotetext{
${ }^{12}$ People are, e.g., asked, "Please try to indicate what you consider to be an appropriate amount for each of the following cases. Under my/our conditions, I would call a net household income per [month] of: about very bad $[\ldots]$ about very good. Please enter an answer on each line [...]" (van Praag 1993).
} 
greater depth what implications income aspirations have, for instance, on redistributive taxation or on public policy in general.

\section{Unemployment and Unhappiness}

Traditionally, economists considered unemployment a social bad with negative consequences for society. The economic policy proposals made by Keynes and his followers were an effort to overcome this ill and to establish full employment. However, the evaluation changed dramatically with the advent of new classical macroeconomics. This school argues that unemployment is voluntary: those not working just refuse to do so at the prevailing wage rate. An important reason why the reservation wage is higher than the prevailing wage is that unemployment benefits are too high. People prefer not to work and to cash in these benefits. Happiness research in economics offers a new approach to productively contribute to this debate about the individual and social costs of unemployment.

\subsection{Unemployment Reduces Subjective Well-Being}

Unemployment first of all reduces the individual well-being of those personally affected. In their innovative work for Britain, Clark and Oswald (1994, p. 655) summarize their results as follows: "Joblessness depresses well-being more than any other single characteristic including important negative ones such as divorce and separation." For Germany, based on individual panel data, Winkelmann and Winkelmann (1998) find a negative effect of personal unemployment on life satisfaction that would require a sevenfold increase in income to compensate. Importantly, in these two analyses, indirect effects (like income losses) that may, but need not, accompany personal unemployment are kept constant. Being unemployed therefore has psychic costs over and above the potential decrease in the material living standard. ${ }^{13}$

High unemployment rates also have non-negligible effects on people who are not personally affected by unemployment. Based on survey data from population samples from European Union member countries between 1975 and 1992, Di Tella et al. (2003) show that aggregate unemployment decreases average reported life satisfaction even if personal unemployment is

\footnotetext{
${ }^{13}$ For references and a discussion of psychological and social factors determining the drop in life satisfaction of people who become unemployed, see Frey and Stutzer (2002a: 95-109). The specific effect of social work norms on unemployed people's subjective well-being is studied empirically in Clark (2003) and Stutzer and Lalive (2004).
} 
kept constant. The question that naturally arises is why even people who are employed feel so much less satisfied with their lives when unemployment rates increase.

\subsection{Costs of High Unemployment for the Employed}

The potential reasons that explain why workers' well-being decreases when unemployment rates increase can be divided into two broad categories: First, a high rate of unemployment may have general negative effects on society that affect everybody in a region. Such reasons include not only the direct effects of unemployment on crime and public finances, but also the general increase in income inequality within a society-an increase that may have the effect of triggering workers' empathy with the unemployed. Second, high unemployment rates affect factors specific to people's individual workplaces.

General effects of unemployment on society. Unemployment leads to social problems that affect people in general. For example, higher unemployment has been observed to increase crime (see, e.g., Raphael and Winter-Ebmer 2001). If higher crime rates are reflected in lower reported well-being, this contributes to the statistical relationship between unemployment rates and subjective well-being.

People also care about the well-being of others and about inequality within a society. Schwarze and Härpfer (2007) present evidence for Germany that people of all income classes report lower life satisfaction when regional income inequality increases. This may be due to inequality aversion and/or to empathy for the poor. Similarly, if economic shocks increase unemployment, people may care about the fate of the people who experience unemployment, reducing their own sense of well-being.

Effects of unemployment on economic security. High unemployment rates have effects on individuals' contemporaneous and future economic situations. In times of high unemployment, the pressure on salaries increases, leading to lower average wages (see the literature on the wage curve by Blanchflower and Oswald 1994). Because income correlates positively with people's well-being, depressed salaries lead to lower life satisfaction in times of high unemployment. Moreover, working conditions may become harsher in times of high unemployment. In particular, actual working hours may rise in recessions as firms cut costs and fear of redundancy and scarcity of alternative job opportunities enable firms to force employees to work more hours than they would prefer (see Stewart and Swaffield 1997, for Britain). This reduces people's leisure time-sometimes without financial compensation. 
The above-mentioned effects on salaries and working hours refer to realized consequences. However, high unemployment also affects anticipated economic distress, as, for instance, the probability that a worker may himself experience a spell of unemployment in the future increases. A large literature documents the importance of self-reported job security on individuals' well-being (see, for example, De Witte 1999, Duncan Gallie et al. 1998, Green 2006). Moreover, people may also expect salary decreases, reduced promotion opportunities and fewer possibilities to change jobs.

In an empirical study, Luechinger et al. (2010) isolate the latter source of reduced individual welfare: the negative anticipatory feelings of angst and stress due to economic insecurity. In order to distinguish between general negative externalities of unemployment and changes in economic risks to individuals, workers are studied in two sectors of the economy that differ fundamentally in their exposure to economic shocks - people working in the private sector and those working in the public sector. Public sector employees usually enjoy extended protection from dismissal and work in organizations that very rarely go bankrupt. Thus, for institutional reasons these workers face a reduced risk of losing their jobs in comparison with workers in the private sector. The empirical analysis uses data from the German SocioEconomic Panel for West Germany between 1984 and 2004. During this period, West Germany experienced large differences and fluctuations in regional unemployment rates from around 4 percent to almost 20 percent. These fluctuations in the unemployment rate over a long period of time allow the authors to identify any sectoral differences in workers' sensitivity to unemployment. Moreover, the panel aspect of the data allows controlling for individual heterogeneity. The general results show that people working in the private sector are affected more strongly by general economic shocks than are those working in the public sector suggesting that a substantial fraction of the psychic costs brought about by general unemployment is due to increased economic insecurity.

In sum, research on happiness has identified two major aspects that are largely neglected in standard economics. The first is that unemployment is not simply an underutilization of resources and not simply a decision between choosing to stay employed (at a low wage), and becoming unemployed (with unemployment benefits). Rather, individuals experience a loss in well-being when being unemployed beyond the reduction in income involved. The second major difference to standard economics is that the utility losses experienced go beyond the persons actually unemployed. Persons with a job are also negatively affected by a higher unemployment rate, one important reason being increased economic insecurity. 
In future research, the various well-being costs of unemployment should be systematically related to labor market institutions.

\section{Happiness Research Challenges the Rational Consumer Hypothesis}

Neoclassical economic theory relies on revealed behavior in order to evaluate the utility generated by the option chosen in a particular decision. This procedure assumes that individuals are perfectly informed about what brings how much utility and that they are perfectly capable of maximizing it. These assumptions imply that people do not make any systematic mistakes when making decisions. If they occurred, individuals would correct them in the long run by learning. Scitovsky (1976) criticized this view as 'unscientific' because "it seemed to rule out - as a logical impossibility - any conflict between what man chooses to get and what will best satisfy him" (p. 4).

This section goes a step beyond standard neoclassical economics. Two extensions of the traditional emphasis on ex ante evaluation and observed decision are insightful. First, the standard economic concept of decision utility can be complemented with the concept of subjective well-being indicating individual welfare judgments (similar to the concept of experienced utility by Kahneman et al. 1997). This separation of concepts makes it possible that orderings of experiences systematically diverge from orderings of options derived from observed behavior. The second extension is closely related to the first, and emphasizes ex post evaluations as a valuable source of information about the possibility of bounded rationality in people's decision-making. How do people fare after they have made decisions? This is particularly relevant if people have limited self-control.

\subsection{Limited Self-control and Individual Well-being}

In standard economics people have no self-control problems. They are able to make decisions according to their long-term preferences. Viewed this way, consuming goods and pursuing activities that some people consider addictive, or at least forming bad habits, such as smoking cigarettes, taking cocaine or watching TV are considered a rational act. Contrary to this view, many people judge their own and other people's consumption behavior as irrational in the sense that they think that they would be better off if they would consume less of these goods and care more for their future well-being.

The revealed preference approach does not allow us to discriminate between the view of consumers as rational actors and consumers mispredicting utility or facing self-control 
problems. However, with a proxy measure for individual welfare at hand, competing theories can be discriminated that make the same predictions concerning individual behavior, but differ in what they put forward as individual utility levels. This kind of test is a powerful tool in challenging theories that proved resistant to a multitude of observed behavior patterns.

The new approach is briefly illustrated for a specific issue, namely TV viewing. ${ }^{14} \mathrm{TV}$ viewing is the most important leisure time activity in modern societies. Revealed preference therefore suggests that, for many people, TV consumption is an important source of well-being. This assessment is in contrast to the mixed appraisal of TV viewing in society. Television has been called a 'plug-in-drug', keeping people glued to the screen and impeding the enjoyment of more valuable experiences. There is a strong popular notion that people watch too much TV. People are prone to weakness of will when faced with the temptation of its immediate benefits with low immediate costs. They watch more than they would like to watch, both ex ante and ex post. ${ }^{15}$

In principle, it is possible to study the claim of systematic errors in TV consumption, based on people's own ex post evaluations. The preferred test would be whether heavy TV viewers experience reduced individual well-being because of their consumption choice.

In a recent study, the subjective well-being of heavy TV viewers in 22 European countries in 2002/03 is analyzed (Frey et al. 2007). Controlling for many individual characteristics, it is found that the more time people spend watching TV, the lower is their reported satisfaction with life, ceteris paribus. The result of the econometric analysis is consistent with the hypothesis that heavy TV viewers suffer significant reductions in their utility because they are

${ }^{14}$ Other possible illustrations would be to smoking (Gruber and Mullainathan 2005) or to obesity (Stutzer 2009; Oswald and Powdthavee 2007).

${ }^{15}$ In economics, the notion of inconsistent time preference is most prominently formulated in models of (quasi) hyperbolic discounting (see, e.g., Laibson 1997). A low discount factor (i.e. a discount factor decreased by $\beta, \beta \in(0,1))$ is applied between the present and some point in time in the near future and a constant discount factor $\delta$ thereafter. An excellent account of the recent extensive empirical and theoretical literature on time inconsistent preferences is provided in Frederick et al. (2002). 
unable to fully control their TV consumption. ${ }^{16}$ However, the result could also reflect that unhappy people spend more time watching TV.

Does having a larger number of TV channels available, i.e. a larger choice set, raise people's subjective well-being? Such a correlation would be expected by standard economic theory. The expansion and diversification of media supply, due to VCR, cable or satellite has, in many countries, gone hand in hand with increased television viewing time (see the collected studies in Becker and Schoenbach 1989). The longer time spent in front of the TV set is consistent with rational consumers (they view the duration optimal for themselves), as well as with TV viewers who are subject to a self-control problem. Preliminary evidence for Israel reports that the introduction of cable TV led to a significant increase in the percentage of viewers agreeing to the statements "I often watch television more than I intend to" $(28 \%$ before the introduction of cable TV and $41 \%$ one year after) and "watching television is often a waste of time" (24\% before the introduction of cable TV and $36 \%$ afterwards) (Weimann 1996). The expanded choice set due to the technological change seems to have led to an increase in the number of people watching more TV than planned, or more than they think is good for them.

While more choice potentially raises individual welfare (if people are able to rationally maximize utility, as is assumed in the traditional economic framework), it is alternatively hypothesized that people with severe self-control problems suffer a utility loss. The positive effect from a potentially better match between TV programs and individual preferences is more than offset by the loss of well-being resulting from over-consumption.

In Benesch et al. (2006), the hypothesis is tested, based on recent data from the European Social Survey and the World Values Survey. In the first step, consumers who possibly have a self-control problem are identified as those people with a large positive residual in a regression equation explaining the amount of TV viewing according to individual sociodemographic characteristics (referred to as "heavy viewers"). In the second step, the effect of

\footnotetext{
${ }^{16}$ Half of the correlation between TV consumption and life satisfaction can be attributed to heavy TV viewers having lower financial satisfaction, attributing more importance to being rich, feeling less secure, trusting other people less and thinking that they are involved less in social activities than their peers. While these correlations are suggestive, it has to be kept in mind that other factors could be driving differences in the different attitudes, as well as in TV viewing. Related evidence is also reported in Bruni and Stanca (2006, 2008), Kasser (2002) and Layard (2005).
} 
a higher number of TV channels on subjective well-being is estimated for heavy TV viewers in comparison with moderate TV viewers. Based on more than 70,000 individual observations from 45 country samples, a statistically significantly negative interaction term between (residual) TV viewing and the number of TV channels is found. In sum, a negative marginal effect of additional TV channels on the well-being of heavy viewers is found. This is consistent with the hypothesis of limited self-control for at least some consumers.

\subsection{The Misprediction of Utility}

Standard economics assumes people can successfully predict utility. In contrast, in many careful experiments and surveys, psychologists have actually studied whether people are successful in forecasting utility which they were about to experience (for reviews, see Loewenstein and Schkade 1999; Wilson and Gilbert 2003; Kahneman and Thaler 2006). While they find that people accurately predict whether an emotional experience primarily elicits good or bad feelings, people often hold incorrect intuitive theories about the determinants of happiness. For instance, they overestimate the impact of specific life events on their experienced well-being with regard to intensity, as well as with regard to duration.

The standard economic model of consumer decisions is probably appropriate for most goods and activities and for most situations. It also applies when individuals make random prediction errors. There are, however, situations in which people have to do a trade off and decide between different activities, goods or options, which systematically differ in the extent to which their future utility can be correctly predicted. If this is the case, systematic economic consequences emerge (Frey and Stutzer 2008). There are options, or attributes of options, that are more salient than others when making a decision, and are thus relatively overvalued. If people choose options according to this evaluation, their experienced utility is lower than what they expected and lower than what they could have experienced if they would not have mispredicted their utility. Moreover, they consume different goods with different attributes and pursue different activities than in a situation where no option in the choice set would have special salience.

Frey and Stutzer (2008) list four major sources for systematic over- and undervaluation of choice options that can be distinguished: (i) the underestimation of adaptation, (ii) distorted memory of past experiences, (iii) the rationalization of decisions, and (iv) false intuitive theories about the sources of future utility. 
The hypothesis that people systematically mispredict utility when faced with some trade-offs links up to various strands of literature where similar phenomena have been identified.

The aspect of underestimated adaptation to new situations has been neatly introduced in theoretical models of intertemporal decision-making (Loewenstein et al. 2003). Based on their model of projection bias, various phenomena can be modeled, like the misguided purchase of durable goods or consumption profiles with too much consumption early on in life. Misprediction of utility thus provides an alternative to seemingly irrational saving behavior that is usually addressed in a framework of self-control problems.

It has been argued that the "work-life balance" of individuals today is distorted. People are induced to work too much and to disregard other aspects of life. This proposition has been forcefully put forward for the United States, where individuals are said to be "overworked" (Schor 1991). This is consistent with misprediction of utility, whereby it is argued that people overvalue income relative to leisure.

Competing for status involves negative externalities and therefore too much effort is invested in gaining status and acquiring "positional goods" (Frank 1985; 1999). Misprediction of utility magnifies the distortions of competing for status in consumption if utility from consumption is overvalued.

Mispredicting utility might also explain people's behavior in court. It has been empirically shown (Tyler et al. 1999) that, when it comes to making decisions, individuals tend to prefer institutions promising favorable outcomes. But ex post they state that they would have preferred an institution putting more emphasis on (just) procedures. This finding suggests that people tend to overvalue outcome relative to procedural utility.

Finally, a study on people's decisions to commute for a longer or a shorter time (Stutzer and Frey 2008) can be understood as an empirical test of the misprediction of utility. The commuting decision involves the tradeoff between the salary or the quality of housing on the one hand and commuting time on the other hand. Rational utility maximizers commute only when they are compensated. However, when people overestimate utility from goods serving extrinsic wants, they are expected to opt for too much commuting and to suffer lower utility. In a large panel data set for Germany, it is found that commuting is not fully compensated, and that, on average, people who commute 22 minutes each way (sample mean) would need an additional 35 percent of their monthly labor income to be as satisfied with their lives as people who do not commute. 
In future research, the tension might be further explored that people face when they have to trade off material and non-material or social goods and activities. Misprediction of utility might be more likely across these two categories of options. When people make trade-offs, material factors get more attention and are overvalued due to the neglect of adaptation, rationalization and memory biases. This would imply consequences with regard to behavior (material goods are over-consumed) and with regard to individual well-being (people are less well off than they would be without mispredicting utility).

\section{The Use of Happiness Research for Public Policy}

Following a constitutional point of view (Buchanan and Tullock 1962, Mueller 1996), there are two levels at which policy decisions are taken: In the current politico-economic process within given rules, and at the constitutional level, where the rules of the game as such are determined. We briefly inquire how the insights gained from happiness research affect public policy at the two levels.

\subsection{Happiness Research for the Current Politico-Economic Process}

One of the major contributions of happiness research directly relevant for public policy refers to the new instruments that enable individuals' preferences and individuals' welfare to be captured. As a consequence, insights of happiness research increase political competition in the current politico-economic process. There is a demand for happiness research by politicians, public officials and representatives of special interest groups as they hope to strengthen their position in the competition for votes or in bargaining for government policies. A case in point is information about the value of public goods and public bads. There are also hopes that a complementary indicator of aggregate happiness might guide policy making more towards citizens' preferences than indicators of aggregate national income alone. In the following, we discuss happiness research in these two areas.

\section{Valuation of Public Goods}

The provision of public goods is a central function of government agencies. More and more often, government agencies are required to provide cost-benefit analyses to back their proposals for government programs. However, the benefits derived from public goods are inherently difficult to measure because they are not exchanged on markets. In reaction to the demand by public agencies and private actors, a wide variety of different approaches for the 
measurement of preferences for public goods have been developed (see, e.g., Freeman 2003). So far, broadly two kinds of valuation methods are applied:

- Stated preference methods. Individuals are directly asked to value the public good in question. The most prevalent method is contingent valuation.

- Revealed preference methods. The behavior of individuals and the complementary and substitutive relationships between public and various marketed goods are used to infer the value attributed to public goods from market transactions in private goods. Examples are the hedonic market approach, the travel cost approach and the averting or mitigating behavior method, to name only the most prominent ones.

Within happiness research, another promising method is emerging. It is called the "Life Satisfaction Approach" (LSA). ${ }^{17}$ With reported subjective well-being as a proxy measure for individual welfare, public goods can be directly evaluated in utility terms. The marginal utility of public goods or the disutility of public bads is estimated by correlating the amount of public goods or public bads with individuals' reported subjective well-being. By measuring the marginal utility of a public good or the marginal disutility of a public bad, as well as the marginal utility of income, the tradeoff ratio between income and the public good can be calculated.

This approach avoids some of the major difficulties inherent in both the stated preference and the revealed preference methods. For instance, the contingent valuation method often faces the problem of the hypothetical nature of the questions asked and the unfamiliarity of the task. Moreover, one cannot exclude the failure of respondents to consider the effect of their budget constraints and substitutes. Symbolic valuation in the form of attitude expression and superficial answers is likely to result (Kahneman and Knetsch 1992). Similarly, the problem of strategic behavior can be addressed only to a limited extent. The LSA is not affected by either of these problems. It does not rely on respondents' ability to consider all relevant consequences of a change in the provision of a public good. It suffices if respondents state their own life satisfaction with some degree of precision. Moreover, there is no reason to expect strategic answering behavior. ${ }^{18}$

\footnotetext{
${ }^{17}$ A review of this approach is provided in Frey et al. (2010).

${ }^{18}$ In more detail, the LSA is compared to the standard non-market valuation techniques in Kahneman and Sugden (2005) and Dolan and Metcalfe (2008).
} 
The LSA has, for example, been used to value air pollution (Luechinger 2009, Welsch 2006), airport noise nuisance (van Praag and Baarsma 2005), terrorism (Frey et al. 2009), droughts (Carroll et al. 2009), and flood hazards (Luechinger and Raschky 2009). Recent studies applying the LSA have already reached a high standard, and the preconditions for its application are better understood and formulated. What so far was an academically driven development of a new method may soon become an empirical tool that is in demand in the political process.

\section{Aggregate happiness indicators as complements to GNP}

Aggregate happiness indicators are increasingly accepted as complements to the longestablished measures of national income, thus following the lead of the social indicators approach and of the capabilities approach (e.g., Sen 1999). The United Kingdom and Australia as well as some other countries are committed to producing national measures of well-being. Recently, a specific module was added to the European Social Survey generating comparative information on a wide range of aspects of individual well-being (Huppert et al. 2009).

Aggregate happiness indicators have several interesting qualities in comparison to traditional measures of economic activity. First, measures of happiness include non-material aspects of human well-being such as the influence of social relations, autonomy, and self-determination. These are excluded, or most insufficiently included, in the traditional national accounts. Second, measures of happiness consider outcome aspects of components already included in GNP via input measures. This holds in particular with respect to the vast area of government activity (measured in GNP by the costs of material and of labor). Third, measures of happiness look at subjectively evaluated outcomes in line with the basic methodological approach of economics. In contrast, the capabilities approach and the „Human Development Index“ by the United Nations look at objectively observable functionings (Sen 1999).

In sum, aggregate happiness indicators provide new and complementary information about preference satisfaction. This information may become a relevant input in the political discourse. So far, robust effects of unemployment and inflation on the popularity and reelection support of governments have been documented (for a review, see Lewis-Beck and Paldam 2000). This research is based on the idea that voters hold governments responsible for the state of the economy and thereby also fuel political competition providing incentives to governments for a sound economic policy. An aggregate happiness indicator might intensify 
this competition as politicians get incentives to justify their actions in terms of a broader and better indicator of individual welfare. It is also useful in strengthening the yardstick competition between political units and political parties. This brings the outcome of the current politico-economic process closer to citizens' preferences. However, not too much should be expected. Aggregate happiness indicators are relatively cheap to assemble. While this allows replicating surveys that seem rigged, it also allows parties to easily come up with yet another measure serving their interest but confusing voters.

\subsection{Happiness Research for the Constitutional Level of Policy}

Happiness research can also provide valuable insights on the constitutional level of public policy. However, this requires that research questions are chosen that relate institutions to reported subjective well-being in a comparative manner. This provides the public with access to information about the institutions that might best allow them to pursue their idea of the good life. Some insights have already been produced, which can be brought into the political discussion process. They include policy issues such as, for example, the role of direct democratic decision making in citizens' well-being (Frey and Stutzer 2000), the effect of mandatory retirement and mandatory schooling on happiness (Charles 2004; Oreopoulos 2007), the consequences of social work norms and birth control rights on women's well-being (Lalive and Stutzer 2010; Pezzini 2005) or the relation between working time regulation and people's subjective well-being (Alesina et al. 2005). However, to our mind, happiness research has so far only skimmed the surface of what promises to become a challenging area of comparative institutional research.

\section{Concluding Remarks}

This review has presented only a selection of possible applications and recent advances in the economic study of individual happiness. Many more have been undertaken. No attempt has been made to be comprehensive. Rather, the intention is to convey to the reader that happiness research by offering a proxy measure for individual welfare opens new ways of tackling old questions, and opens new possibilities to address issues which so far have been difficult, or even impossible, to empirically address. The examples provided cover several fields of study, ranging from income aspirations and unemployment to limited willpower and utility misprediction, suggesting that the new approach may be useful for many different issues in economic research. 
Moreover, economic happiness research can make substantial contributions to a public policy designed to raise individual welfare. At the level of current policy decisions within given rules of the game, the improved measurement of subjective well-being strengthens political competition by allowing decision makers to better evaluate the benefits provided by public goods and to compare various measures assessing the state of society.

At the constitutional level, our vision for the use of happiness research in public policy rests on the fundamental presumption that the quality of the political process is key to people's happiness and that the legitimacy of political action finally rests on the voluntary agreements of the citizens involved. The sovereignty of individuals should not be reduced to their selfreports of well-being. Accordingly, the results gained from happiness research should be taken as inputs into the political process. These inputs still have to prove themselves in political competition and in the discourse among citizens, as well as between citizens and politicians. This vision differs fundamentally from an approach emphasizing the maximization of a social welfare function. Individuals should become more able to advance what constitutes their idea of the good life, both individually and collectively.

There are many open issues for positive analyses in economic research on subjective wellbeing. However, we are convinced that future insights will not only stimulate an old philosophical and profound human debate about individual happiness but actually help to increase it. 


\section{References}

Adler, Matthew D. and Eric A. Posner (2006). New Foundations of Cost-Benefit Analysis. Cambridge, MA, and London, UK: Harvard University Press.

Alesina, Alberto, Edward Glaeser and Bruce Sacerdote (2005). Work and Leisure in the United States and Europe: Why So Different? In: Gertler, Mark and Kenneth Rogoff (eds.). NBER Macroeconomics Annual 2005. Cambridge, MA: MIT Press.

Andrews, Frank M. and Stephen B. Withey (1976). Social Indicators of Wellbeing: American Perceptions of Quality-of-Life. New York: Plenum Press.

Argyle, Michael (1987). The Psychology of Happiness. London: Methuen.

Becker, Lee B. and Klaus Schoenbach (eds.) (1989). Audience Responses to Media Diversification: Coping with Plenty. Hillsdale, NJ: Lawrence Erlbaum Associates.

Benesch, Christine, Bruno S. Frey and Alois Stutzer (2006). TV Channels, Self Control and Happiness. WWZ Discussion Paper 06/03, University of Basel.

Blanchflower, David G. and Andrew J. Oswald (1994). The Wage Curve. Cambridge, MA: MIT Press.

Blanchflower, David G. and Andrew J. Oswald (2004). Well-Being Over Time in Britain and the USA. Journal of Public Economics 88(7-8): 1359-1386.

Bradburn, Norman M. (1969). The Structure of Psychological Wellbeing. Chicago: Aldine Publishing.

Bruni, Luigino and Pier Luigi Porta (eds.) (2005). Economics and Happiness. Framing the Analysis. Oxford: Oxford University Press.

Bruni, Luigino (2006). Civil Happiness. London: Routledge.

Bruni, Luigino and Pier Luigi Porta (eds.) (2007). Handbook on the Economics of Happiness. Cheltenham, UK and Northampton, MA, USA: Edward Elgar.

Bruni, Luigino and Luca Stanca (2006). Income Aspirations, Television and Happiness: Evidence from the World Values Survey. Kyklos 59(2): 209-225.

Bruni, Luigino and Luca Stanca (2008). Watching Alone: Relational Goods, Television and Happiness. Journal of Economic Behavior and Organization 65(3-4): 506-528.

Buchanan, James M. and Gordon Tullock (1962). The Calculus of Consent. Logical Foundations of Constitutional Democracy. Ann Arbor: University of Michigan Press.

Camerer, Colin, George Loewenstein and Matthew Rabin (eds.) (2003). Advances in Behavioral Economics. New York and Princeton: Russell Sage Foundation Press and Princeton University Press.

Campbell, Angus, Philip E. Converse and Willard L. Rodgers (1976). The Quality of American Life: Perceptions, Evaluations, and Satisfactions. New York: Russell Sage Foundation.

Cantril, Albert H. (1965). The Pattern of Human Concern. New Brunswick, NJ: Rutgers University Press.

Carroll, Nick, Paul Frijters and Michael A. Shields (2009). Quantifying the Costs of Drought: New Evidence from Life Satisfaction Data. Journal of Population Economics 22(2): 445-461.

Charles, Kerwin Kofi (2004). Is Retirement Depressing? Labor Force Inactivity and Psychological Well-Being in Later Life. In: Polachek, Solomon W. (ed.). Accounting 
for Worker Well-Being. Research in Labor Economics vol. 23. Amsterdam et al.: Elsevier: 269-299.

Clark, Andrew E. (2003). Unemployment as a Social Norm: Psychological Evidence from Panel Data. Journal of Labor Economics 21(2): 323-51.

Clark, Andrew E. and Andrew J. Oswald (1994). Unhappiness and Unemployment. Economic Journal 104(424): 648-659.

Clark, Andrew, Paul Frijters and Mike Shields (2008). Relative Income, Happiness and Utility: An Explanation for the Easterlin Paradox and Other Puzzles. Journal of Economic Literature 46(1): 95-144.

Csikszentmihalyi, Mihaly (1990). Flow: The Psychology of Optimal Experience. New York: Harper and Row.

Daly, Mary C. and Daniel J. Wilson (2009). Happiness, Unhappiness, and Suicide: An Empirical Assessment. Journal of the European Economic Association 7(2-3): 539-49.

De Witte, Hans (1999). Job Insecurity and Psychological Well-Being: Review of the Literature and Exploration of Some Unresolved Issues. European Journal of Work and Organizational Psychology 8(2): 155-77.

Di Tella, Rafael and Robert MacCulloch (2006). Some Uses of Happiness Data in Economics. Journal of Economic Perspectives 20(1): 25-46.

Di Tella, Rafael, Robert J. MacCulloch and Andrew J. Oswald (2003). The Macroeconomics of Happiness. Review of Economics and Statistics 85(4): 809-27.

Diener, Ed (1984). Subjective Well-Being. Psychological Bulletin 95(3): 542-575.

Diener, Ed and Robert Biswas-Diener (2008). Happiness: Unlocking the Mysteries of Psychological Wealth. Malden, MA: Blackwell.

Diener, Ed and Shigehiro Oishi (2000). Money and Happiness: Income and Subjective WellBeing Across Nations. In: Diener, Ed and Eunkook M. Suh (eds.). Culture and Subjective Well-Being. Cambridge, MA: MIT Press: 185-218.

Diener, Ed, Eunkook M. Suh, Richard E. Lucas and Heidi L. Smith (1999). Subjective WellBeing: Three Decades of Progress. Psychological Bulletin 125(2): 276-302.

Dolan, Paul and Robert Metcalfe (2008). Comparing Willingness-to-Pay and Subjective WellBeing in the Context of Non-Market Goods. Centre for Economic Performance Discussion Paper No. 0890, LSE.

Dolan, Paul, Tessa Peasgood and Mathew White (2008). Do We Really Know What Makes Us Happy? A Review of the Economic Literature on the Factors Associated with Subjective Well-Being. Journal of Economic Psychology 29(1): 94-122

Duesenberry, James S. (1949). Income, Savings and the Theory of Consumer Behavior. Cambridge: Harvard University Press.

Duncan, Gallie, Michael, Michael White, Yuan Cheng and Mark Tomlinson (1998). Restructuring the Employment Relationship. New York: Oxford University Press.

Easterlin, Richard A. (1974). Does Economic Growth Improve the Human Lot? Some Empirical Evidence. In: David, Paul A. and Melvin W. Reder (eds.). Nations and Households in Economic Growth: Essays in Honour of Moses Abramowitz. New York and London: Academic Press: 89-125.

Easterlin, Richard A. (1995). Will Raising the Incomes of All Increase the Happiness of All? Journal of Economic Behavior and Organization 27(1): 35-48. 
Easterlin, Richard A. (2001). Income and Happiness: Towards a Unified Theory. Economic Journal 111(473): 465-484.

Easterlin, Richard A. and Laura Angelescu (2009). Modern Economic Growth and Quality of Life: Cross Sectional and Time Series Evidence. Mimeo, University of Southern California.

Frank, Robert H. (1985). Choosing the Right Pond: Human Behavior and the Quest for Status. New York: Oxford University Press.

Frank, Robert H. (1999). Luxury Fever: Why Money Fails to Satisfy in an Era of Excess. New York, NY: Free Press.

Frederick, Shane, George Loewenstein and Ted O'Donoghue (2002). Time Discounting and Time Preference: A Critical Review. Journal of Economic Literature 40(2): 351-401.

Freeman, A. Myrick, III. (2003). The Measurement of Environmental and Resource Values: Theory and Methods. Washington, DC.: Resources for the Future.

Frey, Bruno S. (2008). Happiness: A Revolution in Economics. Cambridge, MA: MIT Press.

Frey, Bruno S. and Alois Stutzer (2000). Happiness, Economy and Institutions. Economic Journal 110(466): 918-938.

Frey, Bruno S. and Alois Stutzer (2001/02). Economics and Psychology: From Imperialistic to Inspired Economics. Revue de philosophie économique 4: 5-22.

Frey, Bruno S. and Alois Stutzer (2002a). Happiness and Economics: How the Economy and Institutions Affect Well-Being. Princeton and Oxford: Princeton University Press.

Frey, Bruno S. and Alois Stutzer (2002b). What Can Economists Learn from Happiness Research? Journal of Economic Literature 40(2): 402-435.

Frey, Bruno S. and Alois Stutzer (2005). Happiness Research: State and Prospects. Review of Social Economy 62(2): 207-28.

Frey, Bruno S. and Alois Stutzer (eds.) (2007). Economics and Psychology. A Promising New Cross-Disciplinary Field. Cambridge, MA: MIT Press.

Frey, Bruno S. and Alois Stutzer (2008). Economic Consequences of Mispredicting Utility. WWZ Discussion Paper No. 01/08, University of Basel.

Frey, Bruno S., Christine Benesch and Alois Stutzer (2007). Does Watching TV Make Us Happy? Journal of Economic Psychology 28(3): 283-313.

Frey, Bruno S., Matthias Benz and Alois Stutzer (2004). Introducing Procedural Utility: Not Only What, But Also How Matters. Journal of Institutional and Theoretical Economic 160(3): 377-401.

Frey, Bruno S., Simon Luechinger and Alois Stutzer (2009). The Life Satisfaction Approach to the Value of Public Goods: The Case of Terrorism. Public Choice 138(3-4): 317-345.

Frey, Bruno S., Simon Luechinger and Alois Stutzer (2010). The Life Satisfaction Approach to Environmental Valuation. Forthcoming in the Annual Review of Resource Economics.

Green, Francis (2006). Demanding Work. The Paradox of Job Quality in the Affluent Economy. Princeton: Princeton University Press.

Gruber, Jonathan H. and Sendhil Mullainathan (2005). Do Cigarette Taxes Make Smokers Happier? Advances in Economic Analysis and Policy 5(1): 1-43.

Huppert, Felicia A., Nic Marks, Andrew Clark, Johannes Siegrist, Alois Stutzer, Joar Vitters $\varnothing$ and Morten Wahrendorf (2009). Measuring Well-Being Across Europe: Description of 
the ESS Well-being Module and Preliminary Findings. Social Indicators Research 91(3): 301-315.

Inglehart, Ronald F. (1990). Culture Shift in Advanced Industrial Society. Princeton University Press.

Kahneman, Daniel (2000). Experienced Utility and Objective Happiness: A Moment Based Approach. In: Kahneman, Daniel and Amos Tversky (eds.). Choices, Values, and Frames. New York, NY: Cambridge University Press: 673-692.

Kahneman, Daniel and Jack L. Knetsch (1992). Valuing Public Goods: The Purchase of Moral Satisfaction. Journal of Economics and Management 22(1): 57-70.

Kahneman, Daniel and Alan B. Krueger (2006). Developments in the Measurement of Subjective Well-Being. Journal of Economic Perspectives 20(1): 3-24.

Kahneman, Daniel and Robert Sugden (2005). Experienced Utility as a Standard of Policy Evaluation. Environmental and Resource Economics 32(1): 161-81.

Kahneman, Daniel and Richard H. Thaler (2006). Anomalies: Utility Maximization and Experienced Utility. Journal of Economic Perspectives 20(1): 221-234.

Kahneman, Daniel, Peter P. Wakker and Rakesh Sarin (1997). Back to Bentham? Explorations of Experienced Utility. Quarterly Journal of Economics 112(2): 375-405.

Kahneman, Daniel, Ed Diener und Norbert Schwarz (eds.) (1999). Well-Being: The Foundations of Hedonic Psychology. New York, NY: Russell Sage Foundation.

Kahneman, Daniel, Alan B. Krueger, David A. Schkade, Norbert Schwarz and Arthur A. Stone (2004). A Survey Method for Characterizing Daily Life Experience: The Day Reconstruction Method. Science 306(5702): 1776-1780.

Kasser, Tim (2002). The High Price of Materialism. Cambridge, MA: MIT Press.

Kelman, Mark (2005). Hedonic Psychology and the Ambiguities of "Welfare". Philosophy and Public Affairs 33(4): 408-409.

Kimball, Miles and Robert Willis (2006). Utility and Happiness. Mimeo, University of Michigan.

Koivumaa-Honkanen, Heli, Risto Honkanen, Heimo Viinamaeki, Kauko Heikkilae, Jaakko Kaprio and Markku Koskenvuo (2001). Life Satisfaction and Suicide: A 20-Year Follow-up Study. American Journal of Psychiatry 158(3): 433-439.

Koivumaa-Honkanen, Heli, Risto Honkanen, Heimo Viinamäki, Kauko Heikkilä, Jaakko Kaprio, et al. (2000). Self-Reported Life Satisfaction and 20-Year Mortality in Healthy Finnish Adults. American Journal of Epidemiology 152(10): 983-991.

Laibson, David (1997). Golden Eggs and Hyperbolic Discounting. Quarterly Journal of Economics 112(2): 443-477.

Lalive, Rafael and Alois Stutzer (2010). Approval of Equal Rights and Gender Differences in Well-Being. Forthcoming in the Journal of Population Economics.

Lane, Robert E. (2000). The Loss of Happiness in Market Economies. New Haven and London: Yale University Press.

Larsen, Randy J. and Barbara L. Fredrickson (1999). Measurement Issues in Emotion Research. In: Kahneman, Daniel, Ed Diener and Norbert Schwarz (eds.). Well-Being: The Foundations of Hedonic Psychology. New York, NY: Russell Sage Foundation.

Layard, Richard (2005). Happiness: Lessons from a New Science. New York: Penguin. 
Lewis-Beck, Michael S. and Martin Paldam (2000). Economic Voting: An Introduction. Electoral Studies 19(2-3): 113-121.

Loewenstein, George and David A. Schkade (1999). Wouldn't It Be Nice? Predicting Future Feelings. In: Kahneman, Daniel, Ed Diener and Norbert Schwarz (eds.). Well-Being: The Foundation of Hedonic Psychology. New York: Russell Sage Foundation: 85-105.

Loewenstein, George, Ted O'Donoghue and Matthew Rabin (2003). Projection Bias in Predicting Future Utility. Quarterly Journal of Economics 118(4): 1209-1248.

Luechinger, Simon (2009). Valuing Air Quality Using the Life Satisfaction Approach. The Economic Journal 119(536): 482-515.

Luechinger, Simon and Paul A. Raschky (2009). Valuing Flood Disasters Using the Life Satisfaction Approach. Journal of Public Economics 93(3-4): 620-633.

Luechinger, Simon, Stephan Meier and Alois Stutzer (2010). Why Does Unemployment Hurt the Employed? Evidence from the Life Satisfaction Gap between the Public and the Private Sector. Forthcoming in the Journal of Human Resources.

McMahon, Darrin (2006). The Pursuit of Happiness: A History from the Greeks to the Present. London: Allen Lane.

Michalos, Alex C. (1991). Global Report on Student Well-Being, volume 1: Life Satisfaction and Happiness. New York: Springer.

Mueller, Dennis C. (1996). Constitutional Democracy. Oxford: Oxford University Press.

Myers, David G. (1993). The Pursuit of Happiness: Who Is Happy and Why?. New York: Avon.

Nussbaum, Martha and Amartya K. Sen (1993). The Quality of Life. Oxford: Oxford University Press.

Oreopoulos, Philip (2007). Do Dropouts Drop out Too Soon? Wealth, Health, and Happiness from Compulsory Schooling. Journal of Public Economics 91(11-12): 2213-2229.

Oswald, Andrew J. and Nattavudh Powdthavee (2007). Obesity, Unhappiness, and the Challenge of Affluence: Theory and Evidence. Economic Journal 117(521): 441-454.

Pezzini, Silvia (2005). The Effect of Women's Rights on Women's Welfare: Evidence from a Natural Experiment. Economic Journal 115(502): C208-C227.

Rabin, Matthew (1998). Psychology and Economics. Journal of Economic Literature 36(1): $11-46$.

Raphael, Steven and Rudolf Winter-Ebmer (2001). Identifying the Effect of Unemployment on Crime. Journal of Law and Economics 44(1): 259-283.

Rayo, Luis and Gary S. Becker (2007). Evolutionary Efficiency and Happiness. Journal of Political Economy 115(2): 302-337.

Robbins, Lionel C. (1938). Interpersonal Comparisons of Utility: A Comment. Economic Journal 48: 635-41.

Ryan, Richard M. and Edward L. Deci (2001). On Happiness and Human Potentials: A Review of Research on Hedonic and Eudaimonic Well-Being. Annual Review of Psychology 52: 141-166.

Sandvik, Ed, Ed Diener and Larry Seidlitz (1993). Subjective Well-Being: The Convergence and Stability of Self-Report and Non-Self-Report Measures. Journal of Personality 61(3): 317-342. 
Schooler, Jonathan W., Dan Ariely and George Loewenstein (2003). The Pursuit and Assessment of Happiness Can Be Self-Defeating. In: Brocas, Isabelle and Juan D. Carrillo (eds.). The Psychology of Economic Decisions, vol. 1: Rationality and WellBeing. Oxford, UK: Oxford University Press.

Schor, Juliet B. (1991). The Overworked American: The Unexpected Decline of Leisure. Basic Books.

Schwarz, Norbert and Fritz Strack (1999). Reports of Subjective Well-Being: Judgmental Processes and Their Methodological Implications. In: Kahneman, Daniel, Ed Diener and Norbert Schwarz (eds.). Well-Being: The Foundations of Hedonic Psychology. New York, NY: Russell Sage Foundation.

Schwarze, Johannes and Marco Härpfer (2007). Are People Inequality Averse, and Do They Prefer Redistribution by the State? Evidence from German Longitudinal Data on Life Satisfaction. Journal of Socio-Economics 36(2): 233-49.

Scitovsky, Tibor (1976). The Joyless Economy: An Inquiry into Human Satisfaction and Consumer Dissatisfaction. New York: Oxford University Press.

Sen, Amartya K. (1999). Development as Freedom. New York: Alfred Knopf.

Stevenson, Betsey and Justin Wolfers (2008): Economic Growth and Subjective Well-Being: Reassessing the Easterlin Paradox. Brookings Papers on Economic Activity, Spring.

Stewart, Mark B. and Joanna K. Swaffield (1997). Constraints on the Desired Hours of Work of British Men. Economic Journal 107(441): 520-35.

Stiglitz, Joseph E. et al. (2009). Report by the Commission on the Measurement of Economic Performance and Social Progress. Accessible under www stiglitz-sen-fitoussi.fr.

Stone, Arthur A., Saul S. Shiffman and Marten W. DeVries (1999). Ecological Momentary Assessment. In: Kahneman, Daniel, Ed Diener and Norbert Schwarz. Well-Being: The Foundations of Hedonic Psychology (eds.). New York, NY: Russell Sage Foundation: 26-39.

Stutzer, Alois (2004). The Role of Income Aspirations in Individual Happiness. Journal of Economic Behavior and Organization 54(1): 89-109.

Stutzer, Alois (2009). Happiness When Temptation Overwhelms Willpower. In: Dutt, Amitava Krishna and Benjamin Radcliff (eds.). Happiness, Economics, and Politics: Toward a Multi-Disciplinary Approach. Cheltenham, UK: Edward Elgar: 97-126.

Stutzer, Alois, and Bruno S. Frey (2004). Reported Subjective Well-Being: A Challenge for Economic Theory and Economic Policy. Schmollers Jahrbuch: Zeitschrift für Wirtschafts- und Sozialwissenschaften 124(2): 191-231.

Stutzer, Alois and Bruno S. Frey (2008). Stress That Doesn't Pay: The Commuting Paradox. Scandinavian Journal of Economics 110(2): 339-366.

Stutzer, Alois and Rafael Lalive (2004). The Role of Social Work Norms in Job Searching and Subjective Well-Being. Journal of the European Economic Association 2(4): 696719.

Sugden, Robert (2005). Correspondence of Sentiments: An Explanation of the Pleasure of Interaction. In: Bruni, Luigio and Pier Luigi Porta (eds.). Economics and Happiness. Framing the Analysis. Oxford: Oxford University Press.

Sumner, Leonard W. (1996). Welfare, Happiness, and Ethics. Oxford, UK: Oxford University Press. 
Tyler, Tom R., Yuen J. Huo and Edgar Allan Lind (1999). The Two Psychologies of Conflict Resolution: Differing Antecedents of Pre-Experience Choices and Post-Experience Evaluations. Group Processes and Intergroup Relations 2(2): 99-118.

Urry, Heather L., Jack B. Nitschke, Isa Dolski, Daren C. Jackson, Kim M. Dalton, Corina J. Mueller, Melissa A. Rosenkranz, Carol D. Ryff, Burton H. Singer and Richard J. Davidson (2004). Making a Life Worth Living: Neural Correlates of Well-Being. Psychological Science 15(6): 367-372.

van Praag, Bernard M. S. (1968). Individual Welfare Functions and Consumer Behavior-a Theory of Rational Irrationality. North-Holland.

van Praag, Bernard M. S. (1993). The Relativity of the Welfare Concept. In: Nussbaum, Martha and Amarthya K. Sen (eds.). The Quality of Life. Oxford: Clarendon: 362-416.

van Praag, Bernard M. S. and Barbara E. Baarsma (2005). Using Happiness Surveys to Value Intangibles: The Case of Airport Noise. Economic Journal 115(500): 224-246.

van Praag, Bernard M.S. and Ada Ferrer-i-Carbonell (2004). Happiness Quantified - A Satisfaction Calculus Approach. Oxford: Oxford University Press.

Veblen, Thorstein (1899). The Theory of Leisure Class. New York: Modern Library.

Veenhoven, Ruut (1993). Happiness in Nations: Subjective Appreciation of Life in 56 Nations 1946-1992. Erasmus University Press.

Veenhoven, Ruut (1999). Quality-of-Life in Individualistic Society: A Comparison in 43 Nations in the Early 1990s. Social Indicators Research 48(2): 159-188.

Weimann, Gabriel (1996). Cable Comes to the Holy Land: The Impact on Cable TV on Israeli Viewers. Journal of Broadcasting and Electronic Media 40(2): 243-257.

Welsch, Heinz (2006). Environment and Happiness: Valuation of Air Pollution Using Life Satisfaction Data. Ecological Economics 58(4): 801-813.

Wilson, Timothy D. and Daniel T. Gilbert (2003). Affective Forecasting. In: Zanna, Mark (ed.). Advances in Experimental Social Psychology, vol. 35. New York: Elsevier: 345411.

Winkelmann, Rainer and Liliana Winkelmann (1998). Why Are the Unemployed So Unhappy? Evidence from Panel Data. Economica 65(257): 1-15. 